\title{
The effect of lactation and other factors on post-partum changes in body-weight and triceps skinfold thickness
}

\author{
By A. E. DUGDALE AND J. EATON-EVANS* \\ Human Nutrition Research Group, Department of Child Health, University of Queensland, \\ St. Lucia, Q4067, Australia
}

(Received 25 January 1988 - Accepted 22 September 1988)

\begin{abstract}
1. Mothers were followed from 1 month post-partum up to 12 months post-partum to measure changes in their body-weight and triceps skinfold thickness.

2. Overall there was a significant weight loss in the first few months but this levelled off by 7 months.

3. The triceps skinfold increased significantly up to 5 months post-partum and then decreased.

4. These changes in body-weight and skinfold were not affected by the duration of lactation, smoking or the educational achievement of the mothers, but were influenced by the initial body mass index and the desire to lose weight.
\end{abstract}

During pregnancy, both in women and in animals, there is an increase in weight of fat and lean tissues of the mother, quite apart from the products of conception, the uterus and related structures. The amount of fat stored depends on the diet both in human beings (Whitehead et al. 1986) and in rats (van Duijvenvoorde \& Rolls, 1985). The teleological explanation for this is that the mother is storing energy to support the energy demands of lactation, but lactational performance is not affected when little or no fat is deposited during pregnancy (Whitehead et al. 1986). During lactation many mothers (Butte et al. 1984) and animals (McNamara \& Hillers, 1986) decrease both their body-weight and percentage body fat, presumably because the energy needs of lactation plus normal energy needs exceed their energy intake. Others (Vernon \& Finley, 1985; Zammet, 1985) have shown that prolactin alters the responsiveness of adipose tissue to noradrenaline and increases the level of lipoprotein lipase. Illingworth et al. (1986) have shown that there is decreased energy expenditure during lactation. All these studies assume that the changes in body-weight and body composition are the result of lactation. We have examined the changes in body-weight and subcutaneous fat of a group of mothers, some of whom breastfed their infants while others weaned early, and have found that the post-partum changes are similar whether or not the mothers breast-fed their infants.

\section{METHODS}

One hundred and seventy-four mothers participated in a study of the health, growth and feeding of their infants from the age of 1 month to 12 months. We also studied the health, body-weight and social conditions of the mothers. All mothers and their infants lived in the cities of Brisbane and Ipswich in South-east Queensland, Australia. They came from four different localities chosen because of the widely differing socio-economic levels. They were first seen by J.E.-E. at the Maternal and Child Health Clinics when the infant was aged about 2 weeks and then at monthly intervals until the age of 12 months. Some dropped out, mainly because the mother had started working or because they had moved residence. At

\footnotetext{
* Present address: Biomedical Sciences Research Centre, Department of Biology, University of Ulster, Northern Ireland.
} 
each visit the mother was asked about her health and the health of her infant, the types of milk and food given to the infant and also the types of food the mother was taking. The mother's weight and triceps skinfold thickness were measured together with data from the infant. The data were entered into a computer file.

All measurements were done by J.E.-E. A high-quality, bathroom type scale was used for weight, a 'Microtoise' device for height and Harpenden calipers for skinfold. All instruments were checked regularly for zero adjustment and also against standards.

The anthropometric values used in the present report were the weights and triceps skinfolds of the mothers. To allow comparisons between mothers and over the twelve monthly visits, the weight and triceps skinfold of each mother at 1 month post-partum was taken as $100 \%$ and all subsequent values for that mother taken as a percentage of the 1 month value. The data were also analysed to find which factors might have influenced the changes in weight and skinfold. Statistical tests used were means and standard deviations and also multiple linear regression for isolating the effects of factors on the weight and skinfold thickness.

\section{RESULTS}

Values were available on 151 of the 174 women. In the remainder there were no data for the 1 month visit so percentage weights and skinfolds could not be calculated, or they attended for less than 3 months.

The average age of the mothers was $27 \cdot 1$ years (range 17-39 years), the mean body mass index (weight/height ${ }^{2}$; BMI) was 23.9 (range $17 \cdot 3-41 \cdot 3$ ) $; 42 \%$ of the children were the first in the family, $39 \%$ the second child and the remainder the third, fourth or fifth.

The overall changes in body-weight and triceps skinfold are shown in Table 1 . There was clearly a pattern of weight loss from the 1 st month until about the 6 th month when bodyweight levelled off. The changes were statistically significant. There were few drop-outs over the first few months. Even if these were not a random selection of the whole group, they should have had little effect on the overall means and standard deviations. However, towards the end of the 1st year, when numbers remaining in the study were small, the results must be doubtful.

The pattern of change in the triceps skinfold was different from that of the weight. The mean triceps skinfold increased significantly, reaching a peak at about 5 months postpartum. Thereafter it declined steadily until by 1 year it was slightly below the 1 month level.

\section{Factors influencing the changes in weight and triceps skinfold}

The literature suggests that the post-partum changes in body composition are related to the energy demands of lactation. We therefore compared the changes in body-weight and triceps skinfold with varying lengths of lactation. The results shown in Table 2 indicate no major differences between women who breast-fed their infants for varying durations. This was formally tested using the multiple linear regression to separate the independent effects of factors. The factors tested were the duration of breast-feeding, the BMI at 1 month postpartum, the age at which the mother finished formal education (as an indicator of social class) and the mother's desired weight as a percentage of her weight at 1 month postpartum. We also included the amount of cigarette smoking as $1=$ none, $2=$ some days, and 3 = daily. Although these classes are not strictly quantitative they indicate the level of smoking. In each case the dependent variable was the ratio between the value at a time post-partum compared with the level at 1 month post-partum. The results are shown in Table 3.

The duration of breast-feeding, the age at the end of formal education and the present age of the mother had no significant effect on the changes of weight or triceps skinfold 
Table 1. Changes in relative body-weight and triceps skinfold of mothers in the year following delivery

(Mean values and standard deviations)

\begin{tabular}{|c|c|c|c|c|c|}
\hline \multirow{2}{*}{$\begin{array}{c}\text { Period } \\
\text { post-partum } \\
\text { (months) }\end{array}$} & \multirow[b]{2}{*}{$n$} & \multicolumn{2}{|c|}{$\begin{array}{c}\mathrm{Wt} \\
(\% \text { of } 1 \text { month level })\end{array}$} & \multicolumn{2}{|c|}{$\begin{array}{l}\text { Triceps skinfold } \\
\text { (\% of } 1 \text { month level) }\end{array}$} \\
\hline & & Mean & SD & Mean & $\mathrm{SD}$ \\
\hline 1 & 151 & 100 & 0 & 100 & 0 \\
\hline 2 & 149 & 99 & 3 & 108 & 19 \\
\hline 3 & 137 & 99 & 4 & 112 & 20 \\
\hline 4 & 135 & 98 & 4 & 112 & 25 \\
\hline 5 & 131 & 97 & 5 & 113 & 27 \\
\hline 6 & 127 & 96 & 5 & 108 & 26 \\
\hline 7 & 124 & 96 & 5 & 106 & 27 \\
\hline 8 & 122 & 95 & 8 & 106 & 31 \\
\hline 9 & 115 & 96 & 6 & 101 & 28 \\
\hline 10 & 112 & 96 & 6 & 96 & 28 \\
\hline 11 & 93 & 96 & 7 & 99 & 24 \\
\hline 12 & 23 & 98 & 5 & 96 & 32 \\
\hline
\end{tabular}

Table 2. The changes in relative weight and triceps skinfold of mothers with different durations of lactation

(Mean values and standard deviations)

\begin{tabular}{|c|c|c|c|c|c|c|}
\hline \multirow{2}{*}{$\begin{array}{l}\text { Duration of } \\
\text { breast-feeding } \\
\text { (months) }\end{array}$} & \multirow{2}{*}{$\begin{array}{l}\text { Month of } \\
\text { observation }\end{array}$} & \multirow[b]{2}{*}{$n$} & \multicolumn{2}{|c|}{ (\% of I month level) } & \multicolumn{2}{|c|}{$\begin{array}{l}\text { Triceps skinfold } \\
\text { (\% of } 1 \text { month level) }\end{array}$} \\
\hline & & & Mean & SD & Mean & $\mathrm{SD}$ \\
\hline $0-3$ & $\begin{array}{r}3 \\
6 \\
9 \\
11\end{array}$ & $\begin{array}{l}36 \\
30 \\
28 \\
22\end{array}$ & $\begin{array}{l}98 \\
96 \\
97 \\
97\end{array}$ & $\begin{array}{l}4 \\
6 \\
7 \\
2\end{array}$ & $\begin{array}{r}108 \\
106 \\
98 \\
95\end{array}$ & $\begin{array}{r}18 \\
24 \\
21 \\
4\end{array}$ \\
\hline $3.01-6$ & $\begin{array}{r}3 \\
6 \\
9 \\
11\end{array}$ & $\begin{array}{l}26 \\
23 \\
18 \\
12\end{array}$ & $\begin{array}{r}100 \\
98 \\
96 \\
98\end{array}$ & $\begin{array}{l}4 \\
5 \\
6 \\
5\end{array}$ & $\begin{array}{l}116 \\
108 \\
108 \\
102\end{array}$ & $\begin{array}{l}20 \\
21 \\
21 \\
25\end{array}$ \\
\hline$>6$ & $\begin{array}{r}3 \\
6 \\
9 \\
11\end{array}$ & $\begin{array}{l}75 \\
74 \\
69 \\
59\end{array}$ & $\begin{array}{l}99 \\
96 \\
95 \\
96\end{array}$ & $\begin{array}{l}3 \\
5 \\
6 \\
6\end{array}$ & $\begin{array}{l}113 \\
109 \\
101 \\
100\end{array}$ & $\begin{array}{l}21 \\
28 \\
31 \\
24\end{array}$ \\
\hline
\end{tabular}

thickness, while the effect of smoking was statistically significant only in one instance. The biological significance of this single finding must be doubtful. There was a statistically significant result relating the BMI of the mother at 1 month to the change in body-weight at 6 months post-partum. The direction was for mothers with a high BMI to lose less weight or to gain weight. In addition there were several significant associations between BMI at 1 month and changes in triceps skinfold. The plump mothers already had a generous layer of triceps fat, but they tended to increase it still more over the post-partum period. For almost all the mothers, the desired weight was less than the actual weight. There were some significant associations between the desire to lose weight and the actual changes in bodyweight and in triceps skinfold. All were in the same direction; mothers who wanted to lose more weight were likely to do so. 
Table 3. Factors affecting relative body-weight and relative triceps skinfold thickness of mothers from 1 month to 11 months post-partum*

\begin{tabular}{|c|c|c|c|c|c|c|c|c|}
\hline $\begin{array}{c}\text { Age of } \\
\text { infant } \\
\text { (months) }\end{array}$ & $n$ & $\begin{array}{c}\text { All } \\
\text { factors }\end{array}$ & $\begin{array}{l}\text { BMI at } \\
1 \text { month }\end{array}$ & $\begin{array}{c}\text { Duration } \\
\text { of breast- } \\
\text { feeding }\end{array}$ & $\begin{array}{l}\text { Education } \\
\text { (years) }\end{array}$ & Age & Smoking & $\begin{array}{c}\text { Desired } \\
\text { body-wt }\end{array}$ \\
\hline \multicolumn{9}{|c|}{ Effects of maternal factors on relative body-wt } \\
\hline 3 & 135 & NS & NS & NS & NS & NS & NS & NS \\
\hline 6 & 123 & NS & $P<0.05 \dagger$ & NS & NS & NS & NS & $P<0.01 \ddagger$ \\
\hline 9 & 113 & NS & NS & NS & NS & NS & NS & NS \\
\hline 11 & 92 & NS & NS & NS & NS & NS & $P<0.05$ & NS \\
\hline \multicolumn{9}{|c|}{ Effects of maternal factors on relative triceps skinfold thickness } \\
\hline 3 & 135 & NS & NS & NS & NS & NS & NS & NS \\
\hline 6 & 123 & NS & $P<0.05 \dagger$ & NS & NS & NS & NS & $P<0.01 \ddagger$ \\
\hline 9 & 113 & NS & $P<0.05$ & NS & NS & NS & NS & $P<0.05$ \\
\hline 11 & 92 & NS & $P<0.01$ & NS & NS & NS & NS & $P<0.05$ \\
\hline
\end{tabular}

BMI, body mass index (weight/height ${ }^{2}$ ); NS, not significant.

* The relative body-weight was the weight at 3-11 months post-partum divided by the weight at 1 month. Relative triceps skinfold was calculated in the same way.

$\dagger \mathrm{A}$ high BMI at 1 month was associated with a higher relative body-weight or triceps skinfold thickness later.

‡ The change in relative body-weight and triceps skinfold was in the direction of the desired body-weight.

\section{DISCUSSION}

This study involved a diverse sample of mothers but they were not a random sample of the population, so extrapolation from sample to population must be done with care. The multifactorial cross-sectional analyses at different periods after delivery are valid, but the mothers who dropped out of the study may not be a random selection of the test group, so longitudinal comparisons, especially in the later months, are suspect.

The data in the present study confirm the post-partum weight losses reported in women (Butte et al. 1984) and in animals (Vernon \& Finley, 1985). In most of these studies it was assumed that the changes in weight and fat were the result of lactation, but we have shown, as did Naismith \& Ritchie (1975), that the weight loss and changes in skinfolds are independent of the length of breast-feeding. The losses in body tissue must result from a negative energy balance; this cannot be ascribed to lactation but to some other mechanism. Most mothers, particularly those in the upper social classes, want to lose weight after delivery, but in this study the level of maternal education, which was used as an indicator of social class, did not affect the weight loss. The initial level of obesity or leanness was a significant factor. It seems that the underlying factors affecting weight loss may be metabolic, hormonal and deliberate food restriction.

The pattern of change in the triceps skinfold seems paradoxical. All the evidence indicates that fat tissue is lost in the post-partum period. However, Naismith \& Ritchie (1975) found that although subscapular fat was lost in the first 6 months post-partum, there were no significant changes at other sites. It is possible that the high level of oestrogens during pregnancy promotes the gynoid distribution of fat, which is predominantly peripheral, and that this tendency continues for several months after delivery. This would account for the redistribution of fat and a short-term increase of subcutaneous fat in the limbs while the total body mass and the fat mass were decreasing. 
This study was supported by funds from Wyeth Pharmaceuticals Pty Ltd (Australia). The authors thank Dr P. Livingstone, Director General of the Queensland Department of Health, Dr J. MacFarlane and Dr A. Clements, the former and present Directors of the Division of Child Health, the Sisters at the Maternal and Child Health Clinics and also the mothers and infants who participated in this study.

\section{REFERENCES}

Butte, N. F., Garza, C., Stuff, J. E., Smith, E. O. \& Nichols, B. L. (1984). Effect of maternal diet and body composition on lactational performance. American Journal of Clinical Nutrition 39, 296-306.

Illingworth, P. J., Jung, R. T., Howie, P. W., Leslie, P. \& Isles, T. E. (1986). Diminution of energy expenditure during labour. British Medical Journal 292, 437-441.

McNamara, J. P. \& Hillers, J. K. (1986). Adaptations in lipid metabolism of bovine adipose tissue in lactogenesis and lactation. Journal of Lipid Research 27, 150-157.

Naismith, D. J. \& Ritchie, C. D. (1975). The effect of breast-feeding and bottle-feeding on body-weights, skin-fold measurements and food intakes in forty-two primiparous women. Proceedings of the Nutrition Society 14, $116 \mathrm{~A}-117 \mathrm{~A}$.

van Duijvenvoorde, P. M. \& Rolls, B. J. (1985). Body fat regulation during pregnancy, Biochemical Society Transactions 13, 824-825.

Vernon, R. G. \& Finley, E. (1985). Regulation of lipolysis during pregnancy and lactation in sheep: Response to nor-adrenaline and adenosine. Biochemical Journal 230, 222-229.

Whitehead, R. G., Lawrence, M. \& Prentice, A. M. (1986). Maternal nutrition and breast feeding. Human Nutrition: Applied Nutrition 40, Suppl. 1, 1-10.

Zammet, V. A. (1985). Regulation of lipolysis in rat tissues during pregnancy and lactation. Biochemical Society Transactions 13, 831-833. 